\title{
The Penetration of Mobile Technology and Its Implementation on Learning in Indonesian High School
}

\author{
Dwi Sulisworo ${ }^{1}$ and Muqoyyanah ${ }^{2}$ \\ ${ }^{1}$ Universitas Ahamad Dahlan, Indonesia \\ J1. Pramuka No. 42, Umbulharjo, Yogykarta \\ Email: dwi.sulisworo@uad.ac.id \\ ${ }^{2}$ Universiti Pendidikan Sultan Idris, Malaysia \\ Tanjong Malim, Perak Darul Ridzuan 35900 \\ Email: anna.physics87@gmail.com
}

\begin{abstract}
The use of a smartphone as a mobile learning tool in schools is controversial. On the one hand, the teacher prohibits it because it would interfere with the learning process in the classroom; and on the other hand, the teacher saw a lot of potentials can be used from mobile technology. The goal of this study is to describe how the development of secondary schools in Indonesia can facilitate students through the use of mobile learning with the hope that it can be taken at the school level policies to strengthen the existing learning system so that students can achieve optimal learning competencies. This research used descriptive qualitative evaluations to make observations on the application of mobile learning in several secondary schools in several regions in Indonesia during 2015. The results of this study indicate that some of the schools that have implemented mobile learning have a tendency that mobile learning was not planned and structured as a school program; so that the advantages of mobile technology has not been effectively used. Twoimportant things to solve this condition are the availability of government policy and improving teachersliteracy in managing mobile learning application.
\end{abstract}

Keywords: mobile learning, education, teaching and learning, learning strategy, wireless technology

\section{Introduction}

Following $[\mathrm{I}]$ in his research, shows that Indonesians citizen on that year is ready to utilize mobile technology both socially and technologically. However, on the other side, following [2] in his research, shows that school has a paradox where students have already had a good ICT literacy, but has not been facilitated by the school for the learning process itself. It can be called that the usage of the smartphone as the mobile learning device in school is controversial. On the one side, school prohibits it as it will interrupt the learning process in the class; and on the other hand, the teacher saw that lots of potentials could be used from mobile technology $[3,4]$.

The good news, in recent years there is a significance changing in the thought of the teacher in utilizing ICT in the learning process especially in mobile learning. This phenomenon is part of the implication where wireless and mobile technology developed rapidly for the past few years $[5,6]$. The technology becomes more inexpensive and has the higher capability and smaller size. It makes the educator or teacher realize that digital technology provides the opportunity for a different learning process; including the relationship between teacher and student, teacher and teacher, student and student, and also the student with the subject or the competence [7].

This research aims to describe how the development of the secondary school in facilitating the student through the use of mobile learning. The result is hoped that school can take a policy to strengthen the learning system so that the student can achieve their learning competence optimally.

\section{Literary Study The Mobile Technology Penetration in Indonesia}

The use of ICT on several activities of the learning process in Indonesia is seen on a survey written by [8] concerned with the global digital statistic for the past two years (20I4, 2015). Although generally, penetration in Indonesia is up to $28 \%$ in 2015 , there was a significant improvement from 2014 which is only I5\%. There are many development opportunities, in some sectors this improvement could happen.

The time used to access the internet in 2015 is 5.1 hours through laptop devices, and 3.2 hours through mobile devices. It shows the shift towards the mobile devices wherein 2014 the access time through laptop 
devices was 5.5 hours and through mobile devices was 2.5 hours. There is increased access through mobile devices for about 0.7 hours which is $28 \%$. The increase which is relatively high in the shift of laptop devices to mobile devices; although there is a decrease in the global rank from the $3^{\text {rd }}$ rank of 25 countries in 2014 becomes the $7^{\text {th }}$ rank of 3 I countries in 20I5. Whereas in the side of mobile share on the web traffic in 2015, Indonesia contributes $50 \%$ to the $4^{\text {th }}$ rank of 3 I where the global average is $33 \%$. The increase of the use of mobile devices can be seen as opportunities for the learning process in the school, where the activities done by the student with the mobile devices can help them to achieve their competence optimally.

\section{The Definition of Mobile Learning}

Mobile learning (m-learning) is part of the electronic learning or e-learning that give broader opportunities in mobility and more capabilities for student's learning. Therefore, m-learning can be defined differently from elearning concerned with student's mobility as the learner $[3,9]$. The learning can be applied wherever the student is benefited from the existence of mobile technology $[4,10]$. The perspective of mobile learning can be categorized into four categories, those are technocentric, focusing on e-learning, formal education devices, and student-centered learning [II,I2,I3]. Nowadays, the emphasize of technology in school is used to make sure the implementation of active learning with new opportunities and encourage a better learning performance $[7,9,10]$.

\section{Method of Research}

This research is descriptive qualitative evaluation research by having an observation on the implementation of mobile learning in some secondary schools in some regions of Indonesia in 2015. The total of schools observed for the implementation of mobile learning is $\mathrm{IO}$ secondary school in the $\mathrm{I}^{\text {st }}$ grade or $2^{\text {nd }}$ grade on subject physics.

The aspects observed in this research is: kinds of mobile application used in the learning process at school, the reasons of using the mobile learning, the variable observed in the implementation of mobile learning, result and problems found in the implementation of mobile learning, kinds of multimedia used in the learning process, and the learning strategy used.

\section{Research and Discussion Kinds of Mobile Application}

In this research, the application used are Moodle, Edmodo, Path, Facebook and Self-developed application. Moodle is a learning management system with a complete feature. This app can be used either in a
The Penetration of Mobile Technology and Its Implementation...

laptop, tablet or smartphone. Many choices of features can be seen from two sides, that is the high flexibility of teacher and student interaction with the various method but also make a teacher with the limited literacy of the Moodle find it challenging to use. The Features can be used for Journal, Chats, and Forums, Graded Quizzes, Lessons, Book, Wikis, Lightbox galleries, Voicethread, Add Gadgets, and RSS feeds using HTML, Use the Project Format, and Collaborate in Realtime.

Edmodo is a learning management system that inserts parents as the supervisor to watch the student's learning activities. This app can be used both in laptop and other smart devices with social network-based. The features are not as much as in Moodle, but for a particular subject, the features are quite sufficient. The features provided in Edmodo are Polling, Gradebook, Quiz, File and Links, Library, Assignment, Award Badge, Parent Code. This app matches students at the particular level which still need the encouragement of the parents, but in secondary school and above this parent code feature tend to be barely used.

The path is a social network that can be used to share a picture and message. In the beginning, this app is not recommended for learning or education, but individually as an application to reach a broader social network in disseminating information. The high use of this app among teenagers, support the possibility of the user in the learning process. This app has limited features to be used in the learning process. Grading the learning activities cannot be done automatically with the system, but with this app, the users are comfortable and convenient in communicating in the form of text (messaging).

Facebook is an application which relatively similar to the path. It is just Facebook also has a page features that path do not has. This app is the most used app in social media. The page features in Facebook allow the user to share specific themes. Facebook app also can be used for chatting and sharing a document which is more flexible.

The self-developed application is an application made by the teacher to be adjusted with some specific learning strategies. Seen from the modules, generally, this learning management system is also based on the modules that Moodle has. The advantage of this app is it customized by the teacher, but it will be difficult for the teacher with insufficient programming background knowledge.

\section{Reasons for Use}

There are several reasons stated from the research background conducted by teachers in the implementation of mobile learning in the school. First, the need for flexibility for the time of the learning process. It usually happens in the vocational school where the students are doing their field practice; they cannot follow the learning process in the school. In 
returns, they need to follow the class online. Some vocational schools use this reason. It can be said that mobile learning activities can be used as the replacement of activity in the class as the student is somewhere outside the school. The competence to be achieved through mobile learning is also only part of the competence of subject in one semester.

Secondly, it gives opportunities to the student to relearn the subject more freely. At the school like this, there is a tendency that mobile learning is used in line with the learning at school. It can be called as blended learning. Multiple subject and exercises are provided online. The student can relearn the learning subject themselves. A bit different compared to the first reason, in the second reason, mobile learning activities is more likely as a facilitator of the learning process.

From both of the reasons, it can be stated that mobile learning is used only to solve the limitations of the learning process in the class. Mobile learning has not been used as structured and planned activities in the school. The teachers individually initiate to use mobile learning. Several factors cause it such as there is still no national policy that encourages the school to implement the online learning process.

There are several possibilities of the government to do not provide the policy such as consideration of the school infrastructure availability and also the rate of teaching literacy in performing mobile learning. If soon the government still not provide the policy concerned with the implementation of online learning, then the opportunities and the advantages of mobile devices will not encourage the national education development. Mobile activities done by the student is only in the use of social media. It is as shown in data on global digital statistic $[8]$.

\section{The Observed Variable}

Generally, in the implementation of mobile learning in the school observed, the dependent variable seen is the subject understanding level. It is surveyed by giving some exercises related to the subject. The exercises are prepared by observing the taxonomy bloom which match the expected level of understanding, test difficulty, different exercises. Of all the school observed shows that mobile learning can improve the subject understanding significantly

Indeed, the result of the test cannot just only be used for justification. It is because the research that is implemented by the teachers is Quasi-experimental research. It is mean that there are several variables which possibly give an effect and not observed. The possibilities of other variables that also can be seen on the coefficient of determination value (or $\mathrm{R}^{2}$ ) which is around 0.60 in every school. Several factors such as some students follow the additional lesson outside the school, and the duration of time allocated to every
The Penetration of Mobile Technology and Its Implementation...

student to access the provided subject outside the school online. Even so, it still can be said that mobile learning provides opportunities on the improvement of subject understanding.

\section{Learning Strategy}

In general, the learning strategy used in blended learning by using mobile devices is individual learning. It means that the success of learning is determined by the intensity of student interaction with the subject and exercises which are provided online. It can be seen in the learning stage prepared by the teacher in the lesson plan

Although some mobile learning application provides several features, there is a tendency that the main features used are the provision of the learning subject, discussion (synchronous/ asynchronous), exercises and the exam test concerned with the subject. The learning environment is incapable of fostering the self-directed student learning. The student still conducts online learning as the duty from teacher to a particular lesson. It still can be said that the efficiency and the effectiveness of learning by using the advantages of mobile technology, then there should be a policy that should protect this way of learning.

\section{Conclusion}

Nationally, Indonesia undergoes the improvement of mobile technology penetration in various aspects. This condition is still not optimally used to improve student competence in the school lesson. In some schools that implemented mobile learning, there is a tendency that it is still not structured and planned as the school program. This condition makes the advantages that mobile technology used in mobile learning is still ineffective. Two significant things to improve this condition is the availability of government policy and the improvement of teaching literacy in operating mobile learning application.

\section{References}

[1] Sulisworo, D. (2012). The Social Readiness to Implement Mobile Learning in Indonesia. International Conference on Culture, Communication and Multimedia Technology (pp. 387-39I). Yogyakarta: UAD.

[2] Sulisworo, D. (2013). The Paradox on IT Literacy and Science's Learning Achievement in Secondary Schools. International Journal of Evaluation and Research in Education, 2(4), I49-I52.

[3] Tal, H. M., \& Gross, M. (20I4). Teaching Sustainability via Smartphone-Enhanced Experiential Learning in a Botanical Garden. International Journal of Interactive Mobile Technology, 8(I), I0-I5.

[4] Mohammad, H., Fayyoumi, A., \& AlShathry, O. (2015). Do We Have to Prohibit the Use of Mobile Phones in 
Sulisworo \& Muqoyyanah

Classrooms? International Journal of Interactive Mobile Technology, 9(2), 54-57.

[5] Alqahtani, M., \& Mohammad, H. (2015). Mobile Applications' Impact on Student Performance and Satisfaction. TOJET: The Turkish Online Journal of Educational Technology, I4(4), I02-II2.

[6] Sulisworo, D. (2014). Conceptual Model Identification of Personal Learning Environment. Innovation and Development in Teaching and Learning (pp. 37-4I). Perak, Malaysia: UMM.

[7] Babiker, M. E. (2015). For Effective Use of Multimedia in Education, Teachers Must Develop their Own Educational Multimedia Applications. TOJET: The Turkish Online Journal of Educational Technology, I4(4), 62-68.

[8] Kemp, S. (2015). Digital, Social \& Mobile Worldwide in 2015. from We Are Social: http://wearesocial.net
Volume I, Number I, 2018

The Penetration of Mobile Technology and Its Implementation...

[9] Thinley, P., Reye, J., \& Geva, S. (20I4). Tablets (iPad) for MLearning in the Context of Social Constructivism to Institute an Effective Learning Environment. International Journal of Interactive Mobile Technology, 8(I), 16-20.

[10] Ebrahim, H. S., Ezzadeen, K., \& A.K, A. (2015). Acquiring Knowledge through Mobile Applications. International Journal of Interactive Mobile Technology, 9(3), 7I-74.

[II] Chen, C.-H., Chen, S.-H., Hwang, G.-J., \& Yang, T.-C. (2010). Factors influencing teachers' adoption of a ubiquitous technology application in supporting teacher performance. International Journal of Mobile Learning and Organisation, $4(I), 39-54$.

[I2] Crampton, A., Ragusa, A. T., \& Cavanagh, H. (2012). Crossdiscipline investigation of the relationship between academic performance and online resource access by distance education students. Research in Learning Technology, 20, I-I3.

[13] Kukulska-Hulme, A. (2007). Mobile Usability in Educational Contexts: What have we learnt? International Review of Research in Open and Distance Learning, 8(2), I-I2. 